\title{
Study on the Solutions and Existing Problems for Higher Education Management in Market Economy
}

\author{
Lili Liu ${ }^{1, a^{*}}$ and Xuehong Chang ${ }^{1, b}$, \\ ${ }^{1}$ Jilin Agricultural University, Changchun, 130118, China \\ a79856004@qq.com, b 66414623@qq.com
}

Keywords: Market-Oriented Economy; Higher Education; Management; Problems; Solutions

\begin{abstract}
In recent years, the economy in China changed from planned economy to market economy, which stimulates the development of market yet intensifies the competition. Under this circumstance, every industry asks for a glittering array of talents. What's more, along with the integration trend of global economy, talents become the necessity of 21 st century. Colleges, as the place to output talents, its education management quality directly affect it. However, the higher education management still has lots of problems, which severely affect the quality of education. This paper summarizes the existing problems of higher education management and carries out a discussion, hoping to find out solutions.
\end{abstract}

\section{Introduction}

The essence of market is the economy of goods as well as benefits exchanges. Since the reform and opening-up of last century, the planned economy is gradually being replaced and our economy is soaring. However, the implementation of market economy makes the competition more and more severe and the market rule of positive natural selection and values about money strike root in the hearts of the people, which have created huge impact on the industries, especially higher education. The higher education in China generally means higher education implemented in the marketoriented economy society after the reform and opening-up. It has limitations, yet is more superior comparing to the higher education implemented in the beginning of the establishment of People's Republic of China. In recent years, the higher education determines the strategy to serve the economic development. However, from the perspective of education's nature, it is contradictory to politics as well as economy. However, with the gradual development of economy, education plays a more and more important role, especially under the circumstance that market-oriented economy is connecting to international trade and the goal of education is much clearer, which is to serve the economic development. Therefore, education is becoming benefits-oriented and colleges output products rather than talents. Moreover, another characteristics of higher education in the marketoriented economy is that the government intervenes too much. Almost all colleges are funded by the government and the government appoints officers, so the teaching plan is related to the government, which was shaped in the planned economy era and cannot fit the market-oriented economy. Too many intervenes make the condition that schools do not have enough right so the higher education cannot be implemented well. However, in the market-oriented era, higher education has been fundamentally changed and the competition among schools makes the quality of education become better, which is good for students. In addition, the quality of logistics work is also improved because of adequate financial support. In the following, we are going to analyze the problems of higher education in market-oriented economy society.

\section{Existing Problems of Higher Education Management in Market-Oriented Economy}

The Development Time of Higher Education in China Is Short. Higher education in China can be divided into two periods, and higher education in modern times include westernization movement, missionary education, education of Republic of China, which are not developed based on the real situation of China, but a kind of derivatives. At that time, the education did not experience the reform of industrial revolution and it is hasty. Modern education in China, including 
the planned economy education and the education after reform and opening-up cannot be compared to the education of developed and we have to pay tireless efforts to have a place internationally. So, the higher education in early planned economy era aims to serve the economic development, which would inevitably be contradictory to the expectation of higher education. When the planned economy transfers into market-oriented economy, the goal to serve the economic development of higher education does not change. In addition, the government intervenes too much and higher education does not have autonomy rights so there are lots of problems in higher education management. By comprehensively judging the modern higher education, we can find out that it's development time is too short, which still has obvious shortcomings after one-hundred year development. The higher education in China is still going along the same path of western countries, however, we don't have same social systems and as a result, higher education in China cannot create their own features.

Lack of Epochal Character. Education is the fundamental to make a country powerful, especially higher education. So, we have to understand the outline of this era and we have to make changes so as to make this country powerful. However, the current condition of higher education cannot meet this requirement. In the past planned economy era, Chinese government took economic development as the main theme of education while carrying out higher education, which helped China to go through a difficult time. However, with the development of economy, people's living standard improves while the spiritual civilization is poor. That is to say, it is urgent for people to pursue culture and colleges should carry out education based on this target. However, higher education in China has not been improved, which is almost similar to the one in planned economy era. Let's list a simple example, the standard to enroll students. It still adopts the college entrance exam, which makes exam-oriented education system dominant. Even though it can guarantee the fairness, this era asks more of individual development to output talents for various industries rather than cultivating talents for one industry; one more example, the optimal teaching education is to ignite the enthusiasm and interest of students to further cultivate their spirit of exploration and creativeness. However, the education nowadays repeats what the book says, which makes it difficult to achieve the goal of education. Furthermore, higher education without reform demonstrates defeatist scene.

The Problem of Management System of Higher Education. The problem of education system will be a long talk. To be more specific, excessive intervention of the government makes non-profit institutions become profit-oriented. In addition, market-based economy makes the effect of money and competition extends while the topic to serve the economy of higher education becomes more dominant. In addition, the government excessively intervene in education. To begin with, the right of administrative staffs seriously affects the normal education system; secondly, the position competition between administrative staffs and teachers makes colleges to be benefits-oriented. And a sad situation is that few college theaters can quiet down to study on education while most of them are doing projects, winning titles, which can be deemed as the bottlenecks of education reform.

\section{Countermeasures for Solving Existing Problems of Higher Education}

Start from the Point of Education and Seek for Solutions. Higher education in China lags behind western countries and its education philosophy also lags behind, which is divorced from the requirement of the society. However, since the higher education is not perfect, we can grab the chance to develop it. The market-based economy asks higher requirement on education. China has the market-based economy with socialism characteristics, which means we can learn from the development experience of developed countries. However, different systems will lead to different goals and we have to combine the socialist market-based economy to develop to satisfy the requirement of higher education asked by our country. For example, in higher education, colleges should focus on practical training, and remake the standards to enroll and evaluate on them. 
Education System Reform. Among the existing problems of higher education, the education system is prominent. And in order to avoid the infiltration of benefits and money on education, we have to carry out reform. In education system, we should start from two perspectives, including administrative staffs as well as teachers, especially the education right of administrative staffs and the title competition among teachers. In addition, the reform of education should be conducted based on the support of the government to weaken the determined function of administrative staffs during this process, helping them be aware of the condition that they should be supporting rather than dominant; for teachers, the position level should be blurred which should not be taken as the criteria to evaluate them, and we have to value them from the perspective of teaching, performance, research and morality. However education reform will affect the benefits of lots of people and we have to try unremitting efforts to fundamentally change rather than change from the surface

Strengthen the Connection of Higher Education Management with Various Fields. In order to have development, higher education in China cannot work behind closed doors but strengthen the connections with various fields so as to make the function of higher education diverse rather than single economy. To begin with, we have to discuss the relation between higher education management as well as administration. Higher education should be free from the government and vigorously develop its socialist features in market-based economy; secondly, concerning the service, higher education should satisfy the theme of serving the society rather than economy, which is exactly improvement; thirdly, it is the time feature of education management because either the content or the form of education should keep pace with the time such as information technology. Only in this way, will there be development space for higher education.

Regulate the Administrative Function of Government. The function of government for higher education cannot be ignored, which does not mean that the government can excessively intervene. At present, government intervene too much, which is not beneficial to the development of education. In order to help develop higher education, we have to let the government understand their function and position in higher education, and do their work rather than participating in every detailed things, or the administration as well as market-orientation of colleges will be worse. They are the constitutor of education rules but also the performer as well as observer. However, they should only participate in management and development. Management work means that they should coordinate various resources to ensure that colleges can develop toward a right direction; development work means that in market-based economy, the government should carry out macro-control on the development direction and resources. In concrete coordination process, the government is supposed to conduct proper coordination, which should be comprehensive. All in all, the management work should be proper or it will trigger negative effect.

\section{Conclusions}

Education is the fundamental to make a country great, especially for developing countries like China. However, the education in China starts too late and some functions of education are limited in a market-based economy environment. This paper analyzes the problems of higher education, pointing out some solutions, expecting the government will pay attention to so as to make the education play a pivotal role in the new era.

\section{References}

[1] J Li, Problems and Solutions for Existing Problems of Higher Education in Market-based Economy Environment [J]. Training in China, (2016), p.18:85.

[2] X.J. Zhao, Problems and Solutions for Existing Problems of Higher Education in Market-based Economy Environment [J]. Education Science Edition, (2009) No.3, p.60-61+65.

[3] X.Q. Zhang, Problems and Solutions for Existing Problems of Higher Education in Marketbased Economy Environment [J]. Educational Administration Research, (1998) No.03, p.52-54. 
[4] Y.D. Wang, J.X. Li and F.L He, Problems and Solutions for Existing Problems of Higher Education in Market-based Economy Environment [J]. Journal of Changchun University of Technology (Higher Education Study Edition) (2006) No.1, p.39-41.

[5] S.M. Zheng, Solutions for Higher Education Management in Transition to Market-based Economy. [J]. Journal of Dali Teachers College (Social Science Edition) (1995) No. 2, p.22-28.

[6] L. Cong, Problems and Solutions for Existing Problems of Subject Construction in Marketbased Economy Environment [J]. Research and Development Management, (1995) No.6, p.1215.

[7] N.P. Jiang and J. Chen, Discuss on the Rational Disposition of Resources in Market-based Economy Environment [J]. Journal of Higher Education, (1999) No.4, p.26-30.

[8] X.A. Xu, Discuss on the Higher Education Management System Reform in Market-based Economy Environment [J]. Learning Forum, (1999) No.11, p.33-34.

[9] S.K. Gao, Challenges and Solutions for Higher Teacher Education in Market-based Economy Environment [J]. Journal of Xianyang Teachers College, (1996) No.5, p.55-59.

[10] J. Wang, Discuss on the Problems of Higher Education in Market-based Economy Environment [J]. Chinese Geological Education, (1995) No.3, p.:30-33+17. 